HortSCIENCE 25(3):310-312. 1990.

\title{
Paclobutrazol Spray Timing Influences Apple Tree Growth
}

\author{
Ali M. El-Khoreiby ${ }^{1}$, C.R. Unrath ${ }^{2}$, and L.J. Lehman ${ }^{3}$ \\ Department of Horticultural Science, Box 7609, North Carolina State \\ University, Raleigh, NC 27695-7609
}

Additional index words. growth retardant, Malus domestica

\begin{abstract}
A single foliar spray of $250 \mathrm{mg}$ paclobutrazol/liter was applied to 7-yearold 'Oregon Spur Delicious' (OSD) or 'Smoothee Golden Delicious' (SGD) apple trees (Malus domestica Borkh.) at 12 growth stages between tight cluster and petal fall plus 28 days. A linear increase in fruit length and length : diameter ratio and a linear decrease in percent soluble solids content were observed on OSD as sprays were applied later in the season. Russet formation on SGD was excessive if treatment was made between early bloom and petal fall. For both cultivars, best control of shoot growth and minimal change in fruit characteristics occurred when paclobutrazol was applied after bloom. Chemical name used: $\beta$-[(4-chlorophenyl)methyl]- $\alpha-(1,1-$ dimethylethyl)1H-1,2,4-triazole-1-ethanol (paclobutrazol).
\end{abstract}

Controlling vigor of bearing fruit trees can be a formidable task for commercial orchardists. Practices such as branch spreading, the use of size-controlling rootstocks, adjustments in fertilizer and irrigation scheduling, and, in recent years, the use of chemical growth retardants, have all been effective. Paclobutrazol (PB), a synthetic growth retardant, has been reported to reduce vegetative growth of deciduous fruit trees (Quinlan, 1981; Williams, 1984).

Fruit characteristics at maturity may be altered by PB application. Embree et al. (1987) reported a decrease in fruit length and weight after PB treatment, but no change in flesh firmness, soluble solids content, or yield of 'Clapp's Favorite' pear trees. Using 'Redhaven' peach trees, Marini $(1986,1987)$ found that PB application did not influence yield, fruit size, or yield efficiency $\left(\mathrm{kg} / \mathrm{cm}^{2}\right.$ of trunk cross-sectional area). Apple trees that re-

Received for publication 3 Oct. 1988. Paper no. 11829 of the Journal Series of the North Carolina Agricultural Research Service, Raleigh, NC 276957643. The use of trade names in this publication does not imply endorsement by the NCARS of the products named, nor criticism of similar ones not mentioned. The cost of publishing this paper was defrayed in part by the payment of page charges. Under postal regulations, this paper therefore must be hereby marked advertisement solely to indicate this fact.

'Postdoctoral Research Associate. Present address: Dept. of Horticultural Science, Faculty of Agriculture, Suez Canal Univ., Ismailia, Egypt. ${ }^{2}$ Professor.

${ }^{3}$ Graduate Research Assistant. ceived a postbloom foliar spray of PB produced smaller, firmer fruit at harvest (Greene, 1986).

Despite the relatively large number of researchers studying PB, few have considered application timing as a separate response variable (Church et al., 1984; Webster and Andrews, 1985). An application made during different portions of the growing season might produce different responses, depending on various morphological and physiological events in progress at application time. The objective of this study was to determine the effect of PB foliar spray timing on vegetative growth and fruiting of mature 'Delicious' and 'Golden Delicious' apple trees.

A randomized complete-block design with 13 treatments, which included an unsprayed check treatment, and four whole-tree replicates per treatment was used. Seven-year-old 'Oregon Spur Delicious' and 'Smoothee Golden Delicious' trees on MM.106 rootstock growing in a commercial orchard in western North Carolina were chosen for study. A single foliar application of paclobutrazol (Cultar 2SC) at $2.50 \mathrm{mg} \cdot$ liter $^{-1}$ plus $0.1 \%$ Tween 20 surfactant was made based on flower developmental stage. The 12 stages tested were tight cluster, first pink, full pink, early bloom, full bloom, petal fall (PF), and $\mathrm{PF}+3,7,10,14,21$, and 28 days. Each foliar treatment was made using a $\mathrm{CO}_{2}$-powered backpack sprayer (Model T, R\&D Sprayers, Opelousas, La.) that delivered spray at $\approx 1.7$ liters $\cdot \mathrm{min}^{-1}$. Applications were made to the drip point and averaged $1.5 \mathrm{~min} /$ tree.

Four nonfruiting, vigorous lateral shoots 
Table 1. 'Oregon Spur Delicious' fruit characteristics at maturity and shoot growth between petal fall and petal fall plus 52 days as affected by paclobutrazol spray timing.

\begin{tabular}{|c|c|c|c|c|c|c|}
\hline \multirow[b]{2}{*}{$\begin{array}{l}\text { Flower stage } \\
\text { at time of } \\
\text { application }\end{array}$} & \multicolumn{5}{|c|}{ Fruit } & \multirow[b]{2}{*}{$\begin{array}{l}\text { Shoot } \\
\text { growth } \\
(\mathrm{cm})\end{array}$} \\
\hline & $\begin{array}{l}\text { Length } \\
(\mathrm{cm})\end{array}$ & $\begin{array}{c}\text { Diam } \\
(\mathrm{cm})\end{array}$ & $\begin{array}{l}\text { Length : diam } \\
\text { ratio }\end{array}$ & $\begin{array}{c}\text { Firmness } \\
(\mathrm{N})\end{array}$ & $\begin{array}{c}\text { Soluble } \\
\text { solids } \\
(\%)\end{array}$ & \\
\hline Tight cluster & 6.2 & 7.8 & 0.80 & 71 & 14.2 & 19.2 \\
\hline First pink & 5.9 & 7.5 & 0.79 & 65 & 14.4 & 13.6 \\
\hline Full pink & 6.0 & 7.4 & 0.81 & 70 & 14.5 & 19.7 \\
\hline Early bloom & 5.5 & 7.3 & 0.75 & 85 & 15.6 & 24.7 \\
\hline Full bloom & 5.8 & 7.2 & 0.81 & 83 & 14.1 & 21.1 \\
\hline Petal fall (PF) & 5.8 & 7.5 & 0.77 & 74 & 14.5 & 15.9 \\
\hline $\mathrm{PF}+3$ days & 6.4 & 7.9 & 0.81 & 75 & 14.4 & 13.8 \\
\hline $\mathrm{PF}+7$ days & 6.5 & 7.7 & 0.80 & 72 & 13.8 & 13.3 \\
\hline$P F+10$ days & 6.1 & 7.6 & 0.81 & 74 & 14.1 & 22.3 \\
\hline $\mathrm{PF}+14$ days & 6.3 & 7.7 & 0.82 & 68 & 13.7 & 9.2 \\
\hline $\mathrm{PF}+21$ days & 6.2 & 7.6 & 0.82 & 69 & 13.3 & 7.5 \\
\hline $\mathrm{PF}+28$ days & 6.4 & 7.7 & 0.84 & 70 & 13.3 & 17.6 \\
\hline No application & 6.2 & 7.7 & 0.84 & 67 & 14.1 & 17.2 \\
\hline \multicolumn{7}{|c|}{ Regression significance } \\
\hline Linear & 0.0107 & 0.1405 & 0.0098 & 0.2766 & 0.0001 & 0.1073 \\
\hline Quadratic & 0.3167 & 0.6723 & 0.2399 & 0.0386 & 0.1518 & 0.8585 \\
\hline
\end{tabular}

${ }^{2}$ Trees received $250 \mathrm{mg}$ paclobutrazol/liter as a foliar spray at one of 12 growth stages. Fruit characteristics are means of 80 observations per treatment. Sixteen vigorous terminal shoots per treatment averaged for vegetative measurements.

Table 2. Orthogonal contrast significance of 'Delicious' and 'Golden Delicious' apple fruit characteristics at maturity and shoot growth between petal fall and petal fall plus 52 days.

\begin{tabular}{|c|c|c|c|c|c|c|c|c|}
\hline \multirow{2}{*}{$\begin{array}{l}\text { Orthogonal } \\
\text { contrast }\end{array}$} & \multirow[b]{2}{*}{ Length } & \multirow[b]{2}{*}{ Diam } & \multirow{2}{*}{$\begin{array}{l}\text { Length : diam } \\
\text { ratio }\end{array}$} & \multirow[b]{2}{*}{ Firmness } & \multirow{2}{*}{$\begin{array}{l}\text { Percent } \\
\text { soluble } \\
\text { solids }\end{array}$} & \multicolumn{2}{|c|}{ Percent russet } & \multirow{2}{*}{$\begin{array}{l}\text { Shoot } \\
\text { growth }\end{array}$} \\
\hline & & & & & & Net & Solid & \\
\hline Check vs. treated & 0.5501 & 0.3348 & $\begin{array}{l}\text { Delicious } \\
0.9248\end{array}$ & 0.0318 & 0.8038 & --- & --- & 0.8625 \\
\hline Check vs. prebloom & 0.1409 & 0.0892 & 0.6037 & 0.0095 & 0.1329 & --- & --- & 0.5987 \\
\hline Check vs. postbloom & 0.9249 & 0.7261 & 0.5912 & 0.0935 & 0.4837 & --- & --- & 0.5010 \\
\hline Pre- vs. postbloom & 0.0006 & 0.0107 & 0.0028 & 0.0418 & 0.0001 & --- & --- & 0.0409 \\
\hline Bloom vs. postbloom & 0.0001 & 0.0030 & 0.0008 & 0.0001 & 0.0001 & --- & --- & 0.0305 \\
\hline \multicolumn{9}{|c|}{ Golden Delicious } \\
\hline Check vs. treated & 0.0125 & 0.0408 & 0.1213 & 0.1191 & 0.5751 & 0.5912 & 0.1414 & 0.8246 \\
\hline Check vs. prebloom & 0.0097 & 0.0294 & 0.1350 & 0.4218 & 0.7102 & 0.5154 & 0.0313 & 0.1120 \\
\hline Check vs. postbloom & 0.0224 & 0.0684 & 0.1349 & 0.0457 & 0.2311 & 0.6744 & 0.3903 & 0.4178 \\
\hline Pre- vs. postbloom & 0.1502 & 0.2529 & 0.3162 & 0.2106 & 0.0523 & 0.0064 & 0.0026 & 0.0004 \\
\hline Bloom vs. postbloom & 0.0015 & 0.0101 & 0.0253 & 0.3976 & 0.2958 & 0.0007 & 0.0001 & 0.0087 \\
\hline
\end{tabular}

${ }^{2}$ Trees received $250 \mathrm{mg}$ paclobutrazol/liter as a foliar spray at one of 12 stages between tight cluster and petal fall plus 52 days. Fruit characteristics are means of 80 observations per treatment. Sixteen vigorous terminal shoots per treatment averaged for vegetative measurements. Arcsin-transformed percent net and solid russet were used in analysis.

Table 3. 'Smoothee Golden Delicious' fruit characteristics at maturity and shoot growth between petal fall and petal fall plus 52 days as affected by paclobutrazol spray timing.

\begin{tabular}{|c|c|c|c|c|c|c|c|c|c|}
\hline \multirow{3}{*}{$\begin{array}{l}\text { Flower stage } \\
\text { at time of } \\
\text { application }\end{array}$} & \multicolumn{6}{|c|}{ Fruit } & & & \multirow{3}{*}{$\begin{array}{l}\text { Shoot } \\
\text { growth } \\
(\mathrm{cm})\end{array}$} \\
\hline & \multirow{2}{*}{$\begin{array}{l}\text { Wt } \\
(\mathrm{g})\end{array}$} & \multirow{2}{*}{$\begin{array}{l}\text { Length } \\
(\mathrm{cm})\end{array}$} & \multirow{2}{*}{$\begin{array}{c}\text { Diam I } \\
(\mathrm{cm})\end{array}$} & \multirow{2}{*}{$\begin{array}{l}\mathrm{h}: \text { diam } \\
\text { ratio }\end{array}$} & \multirow{2}{*}{$\begin{array}{c}\text { Firmness } \\
(\mathrm{N})\end{array}$} & \multirow{2}{*}{$\begin{array}{c}\text { Soluble } \\
\text { solids } \\
(\%)\end{array}$} & \multicolumn{2}{|c|}{ Russet (\%) } & \\
\hline & & & & & & & Net & Solid & \\
\hline Tight cluster & 132 & 5.8 & 6.9 & 0.83 & 69 & 16.4 & 21 & 16 & 14.4 \\
\hline First pink & 134 & 6.0 & 6.8 & 0.88 & 69 & 17.1 & 17 & 14 & 11.2 \\
\hline Full pink & 129 & 5.8 & 6.7 & 0.85 & 69 & 16.7 & 23 & 25 & 11.7 \\
\hline Early bloom & 105 & 5.1 & 6.3 & 0.82 & 73 & 16.3 & 24 & 40 & 17.3 \\
\hline Full bloom & 109 & 5.4 & 6.3 & 0.86 & 80 & 17.1 & 20 & 47 & 9.2 \\
\hline Petal fall (PF) & 118 & 5.4 & 6.6 & 0.83 & 80 & 17.8 & 33 & 30 & 7.2 \\
\hline $\mathrm{PF}+3$ days & 132 & 5.7 & 6.8 & 0.85 & 75 & 16.9 & 24 & 23 & 9.0 \\
\hline $\mathrm{PF}+7$ days & 121 & 5.6 & 6.6 & 0.86 & 77 & 17.9 & 23 & 19 & 8.3 \\
\hline $\mathrm{PF}+10$ days & 115 & 5.5 & 6.5 & 0.85 & 78 & 18.0 & 15 & 22 & 6.8 \\
\hline $\mathrm{PF}+14$ days & 133 & 5.7 & 6.8 & 0.83 & 75 & 17.4 & 16 & 22 & 5.5 \\
\hline $\mathrm{PF}+21$ days & 144 & 6.0 & 7.0 & 0.85 & 73 & 16.9 & 16 & 10 & 4.3 \\
\hline $\mathrm{PF}+28$ days & 129 & 5.8 & 6.7 & 0.86 & 76 & 17.2 & 14 & 11 & 8.2 \\
\hline No application & 148 & $6: 1$ & $7: 1$ & 0.86 & 69 & 16.9 & 19 & 14 & 8.9 \\
\hline \multicolumn{10}{|c|}{ Regression significance } \\
\hline Linear & 0.4351 & 0.4705 & 0.566 & 0.5541 & 0.0870 & 0.0909 & 0.02 & .000 & 0.0002 \\
\hline Quadratic & 0.3442 & 0.0434 & +0.070 & 0.2928 & 0.0199 & 0.0577 & 0.03 & 0.100 & 0.1008 \\
\hline
\end{tabular}

${ }^{2}$ Trees received $250 \mathrm{mg}$ paclobutrazol/liter as a foliar spray at one of 12 growth stages. Fruit characteristics are means of 80 observations per treatment. Sixteen vigorous terminal shoots per treatment averaged for vegetative measurements. Arcsin-transformed percent net and solid russet were used in regression analysis. about equidistant around each tree were tagged and extension growth recorded four times between $\mathrm{PF}$ and $\mathrm{PF}+52$ days. A random 20 -fruit sample was collected from each tree at estimated fruit maturation of control trees. Individual fruit length, diameter, weight, color, flesh firmness, and soluble solids content (SSC) were determined on each fruit. 'Delicious' fruit color was rated using two 20-point scales: 1) percent of fruit surface being nongreen, which ranged from $0 \%$ (solid green) to $100 \%$ (solid red) and 2) percent of fruit surface being solid dark red, which ranged from $0 \%$ (light red) to $100 \%$ (dark red). 'Golden Delicious' fruit color was rated on a S-point scale ranging from 1 (solid green) to 5 (uniformly bright yellow). Fruit firmness was measured on two opposite sides of each peeled fruit using a Magness-Taylor tester equipped with an 11-mm plunger. The SSC was tested individually using a handheld refractometer. In addition, 'Smoothee Golden Delicious' fruit were rated on the percentage of fruit surface with net and solid russet using 20-point scales ranging from $0 \%$ (no russet) to $100 \%$ (solid russet). Crop load after June drop was estimated by two independent raters using a lo-point scale ranging from $0 \%$ (no crop) to $100 \%$ (extremely heavy set).

A regression analysis was performed on all data using flower stage as the regressor variable. In addition, several orthogonal contrasts were investigated.

'Oregon Spur Delicious' crop load at the end of June drop was reduced to $40 \%$ of full crop or lower when PB application was made between early bloom and PF plus 10 days (data not shown). Application before or after this period resulted in at least $88 \%$ of estimated full crop load. Other researchers have also noted that treatment close to bloom time can adversely influence fruit load. After a foliar spray of PB at cytokinesis, Webster and Andrews (1985) reported increased plum abscission. Using apple trees, Church et al. (1984) observed a decrease in final fruit set after PB treatment made before flowering or at PF. In our study, crop load of 'Smoothee Golden Delicious' was not affected by treatment at any flower stage.

Fruit weight, fruit diameter, and shoot growth of 'Delicious' were not significantly affected by time of application (Table 1). Fruit skin color at maturity was not altered by application timing (data not shown). However, 'Delicious' fruit length and length : diameter ratio increased linearly as PB treatment was made later in the growing season, while percent SSC exhibited a linear decrease (Table 1). Fruit firmness peaked for PB treatment at early and full bloom, and the quadratic regression term for 'Delicious' fruit firmness was significant at $P=0.0386$ (Table 1).

Compared to untreated trees, pre- or postbloom application of PB to 'Delicious' trees had little influence on fruit characteristics or shoot growth (Table 2). Application before bloom resulted in reductions in fruit length, diameter, and length : diameter ratio, greater firmness, higher SSC, and more shoot growth, 
compared to an application after bloom (Table 2). Similar trends for each of these variates were observed in the bloom vs. postbloom contrast in Table 2 .

Neither linear nor quadratic relationships were evident for 'Smoothee Golden Delicious' fruit weight, diameter, length : diameter ratio, or percent SSC (Table 3). As PB treatment was made later in the season, significant linear decreases in shoot growth and percent net and solid russet were revealed (Table 3). Quadratic terms were significant for 'Golden Delicious' fruit length, firmness, and percent net russet (Table, 3).

Compared to fruit from untreated 'Golden Delicious' trees, application of PB resulted in shorter fruit with a smaller diameter and more solid russet (Table 2). Trees that received a postbloom treatment bore fruit that were shorter and less firm at harvest than fruit from untreated trees (Table 2). Prebloom applications resulted in lower SSC at maturity and more net and solid russet, as well as longer shoot growth than a postbloom application (Table 2). Treatment with $\mathrm{PB}$ at bloom resulted in fruit with shorter lengths and smaller diameters, more net and solid russet, and longer shoots compared to application after bloom (Table 2).

Richardson et al. (1986) reported an increase in severe smooth russeting of apples after applying PB plus surfactant 3.5 weeks after bloom. In our study, treating 'Golden Delicious' with a low concentration of PB around bloom time resulted in unacceptable increases in russeting, which would reduce market value considerably.

Frequently, orchardists would like to control apple tree extension growth without adversely affecting fruit characteristics. Because PB concentrations $>1000 \mathrm{mg} \cdot$ liter $^{-1}$ have caused undesirable responses (Embree et al., 1987; Greene, 1986; Looney and McKellar, 1987; Richardson et al., 1986), testing of lower rates may be justified. Using a lower rate, we found that postbloom applications generally provided better control of 'Delicious' shoot growth and minimal change in fruit size and quality, compared to bloom or prebloom applications. For 'Golden Delicious', application before or during bloom provided more shoot growth control than postbloom application, and timing had a significant effect on fruit characteristics. Postbloom application appeared to minimize undesirable increases in net and solid russet. Knowing how spray timing influences tree response will allow growers to obtain some control over vegetative growth, while minimizing reductions in fruit size and quality.

\section{Literature Cited}

Church, R.M., L. Copas, and R.R. Williams. 1984. Changes in fruit set, leaf size, and shoot growth of apple caused by some fungicides, insecticides and a plant growth regulator. J. Hort. Sci. 59:161-164.

Embree, C.G., W.E. Craig, and F.R. Forsyth. 1987. Effect of daminozide, chlormequat and paclobutrazol on growth and fruiting of 'Clapp's Favorite' pear. HortScience 22:55-56.

Greene, D.W. 1986. Effects of paclobutrazol and analogs on growth, yield, fruit quality, and storage potential of 'Delicious' apples. J. Amer. Soc. Hort. Sci. 111:328-332.

Looney, N.E. and J.E. McKellar. 1987. Effects of foliar- and soil surface-applied paclobutrazol on vegetative growth and fruit quality of sweet cherries. J. Amer. Soc. Hort. Sci. 112:71-76.

Marini, R.P. 1986. Growth and cropping of 'Redhaven' peach trees following foliar applications of flurprimidol and paclobutrazol. J. Amer. Soc. Hort. Sci. 111:849-853.

Marini, R.P. 1987. Growth and cropping of 'Redhaven' peach trees following soil application of paclobutrazol. J. Amer. Soc. Hort. Sci. 112:1821.

Quinlan, J.D. 1981. New chemical approaches to the control of fruit tree form and size. Acta Hort. 120:95-105.

Richardson, P.J., A.D. Webster, and J.D. Quinlan. 1986. The effect of paclobutrazol sprays with or without the addition of surfactants on the shoot growth, yield and fruit quality of the apple cultivars Cox and Suntan. J. Hort. Sci. 61:439-446.

Webster, A.D. and L. Andrews. 1985. Fruit thinning Victoria plums (Prunus domestica L.): Preliminary studies with paclobutrazol. J. Hort. Sci. 60:193-199.

Williams, M.W. 1984. Use of bioregulators to control vegetative growth of fruit trees and improve fruiting efficiency. Acta Hort. 146:97104. 